\title{
New venture entrepreneurship and context in East Asia: a systematic literature review
}

\author{
Martin Hemmert ${ }^{1}$ (D) - Adam R. Cross ${ }^{2}$. Ying Cheng ${ }^{3}$. Jae-Jin Kim ${ }^{4}$. \\ Masahiro Kotosaka ${ }^{5} \cdot$ Franz Waldenberger $^{6} \cdot$ Leven J. Zheng $^{7}$
}

Received: 11 February 2021 / Revised: 23 July 2021 / Accepted: 1 August 2021 /

Published online: 21 August 2021

(c) The Author(s) 2021

\begin{abstract}
While research on new venture entrepreneurship has been predominantly conducted in Western countries, East Asian start-ups have gained global relevance in recent years. In this article, we systematically review studies on new venture entrepreneurship in East Asia published in Social Science Citation Index (SSCI)-listed journals between 2000 and 2020 and find that the number of papers annually published has been rapidly increasing. However, the research body is highly unbalanced, as most articles are single-country studies focused on China, apply a quantitative methodology, and concentrate on topics such as entrepreneurial strategies and new venture entrepreneurs' personal attributes and networks. Moreover, a majority of studies provides no or only a weak consideration of the national or subnational context. More strongly contextualized research on countries such as Japan and South Korea and on less studied themes such as culture, entrepreneurial financing, entrepreneurial teams, new venture internationalization and new venture entrepreneurial intention is desirable.
\end{abstract}

Keywords New venture entrepreneurship · East Asia · Contextualization · Systematic literature review

\section{Introduction and research questions}

New ventures - defined here as new organizations established to exploit a repeatable and scalable business model-play a key role in the creation of wealth, employment, industries, innovations and growth in an economy, as well as fostering novel solutions to both social and environmental problems (Shepherd et al., 2021). In recognition of the important contribution made by new ventures to development, scholarly

Martin Hemmert

mhemmert@korea.ac.kr

Extended author information available on the last page of the article 
literature on entrepreneurship in general, and on new ventures and start-ups in particular, has expanded rapidly over the past few decades (Ferreira et al., 2019). This is particularly evident for research on East Asian new ventures, not least because East Asia is now increasingly rivaling North America and Europe in providing a conducive and supportive environment for the creation, growth and exit of entrepreneurial new ventures. According to Startup Genome (2020), by the end of 2019 seven of the top thirty global centers of entrepreneurship were located in East Asia, compared with eleven in the USA, five in Europe and seven in the rest of the world. In 2020, the established entrepreneurial ecosystems of Beijing (ranked 4th), Shanghai (8th), Tokyo (15th), and Hong Kong (29th) were joined by Seoul (20th), Shenzhen (22nd) and Hangzhou (28th) in Startup Genome's Top 30 Global Startup Ecosystems ranking, as measured by indicators such as new venture and exit valuations, funding opportunities, infrastructure quality, market size and reach, and knowledge and talent availability. Moreover, by July 2021, 176 of the world's most valuable unicorn companies (i.e. private start-up companies with a valuation in excess of US\$ 1bn) were from East Asia; in particular Mainland China (155), Hong Kong SAR (5), Japan (6) and South Korea (10) (CB Insights, 2021). This number is lower than that of the USA (378), but greatly exceeds that for Europe (92) and the rest of the world (104).

As for other parts of the world (Shepherd et al., 2019), numerous scholars have employed a diverse range of theories and methodological approaches to explain a wide variety of phenomena associated with different stages in the life cycle of young East Asian firms, ranging across the initiation, engagement processes and performance of entrepreneurial activities, and the environmental conditions within which these endeavors take place. However, all this has generated a complex, multifaceted and fragmented body of literature that contains multiple perspectives, levels of analysis, and theoretical underpinnings. Therefore, it is now timely to take stock of the state of research on East Asian new ventures in order to identify key themes in the literature and to propose future research opportunities.

At the same time, it is also pertinent to now examine the extent to which the existing body of literature on East Asian new ventures takes account of context. From a management research perspective, context can be defined as the circumstances, conditions, situations or environments that are external to the phenomenon in question, and that enable or constrain it (Welter, 2011). Within the entrepreneurship literature in general, there have been numerous calls for scholars to acknowledge and account for the context in which entrepreneurship occurs (e.g., Welter \& Gartner, 2016; Zahra, 2007; Zahra et al., 2014). Context matters in this research domain because it influences the range of opportunities, activities and outcomes available to the entrepreneurial founders of a start-up, the assets they are able to access and the liabilities they encounter, as well as setting boundaries for their actions (Fitz-Koch et al., 2018). In short, context is important for "understanding when, how and why entrepreneurship happens, and who becomes involved" (Welter, 2011, p. 166). While acknowledging the multifaceted nature of 'context' as a concept, Welter (2011) identifies four dimensions of context for entrepreneurship, namely 'business' (i.e. industries and markets), 'social' (i.e. networks, including households and families), 'spatial' (i.e. geographical 
environments such as countries, communities, neighborhoods, industrial districts and clusters) and 'institutional' (i.e. culture and society, and political and economic systems). However, most extant entrepreneurship research has been conducted in Western settings, especially in the Anglo-Saxon countries of the USA, UK and Canada (Jones et al., 2011; Knight \& Liesch, 2016; Meyer et al., 2014). This is problematic, since the context within which entrepreneurship happens is different between Western and East Asian countries (Hemmert et al., 2019; Huang et al., 2020; Meyer, 2007). As Bruton et al. (2018) observe, research on East Asian new ventures may miss key elements of entrepreneurship because of an over-reliance on Western-based theoretical values, foundations, and analytical frameworks and models.

As the literature on entrepreneurship has grown, so has the number of literature reviews in the field (e.g., (Jones et al., 2011; Knight \& Liesch, 2016; Unger et al., 2011). However, there are few recent literature reviews on entrepreneurship in East Asia. Jing et al. (2015) observe that the cultural and social context is less strongly considered in entrepreneurship studies in China than in Western countries, while Chen et al. (2020) propose that the uneven development across subnational regions, the important role of government and conflicting goals among ecosystem participants are future research topics for entrepreneurial ecosystems in China. Huang et al. (2020) review Chinese entrepreneurship research and categorize studies according to the type of contextualization that has been applied. Overall, while aspects of entrepreneurship research have been reviewed in a comparative manner by contrasting China with Western countries, no comprehensive review on new venture entrepreneurship research has been conducted yet across East Asia as a whole, including China, Japan and South Korea (hereafter: Korea).

The aim of this paper, therefore, is to provide an overview of the existing body of literature on new ventures in East Asia, to identify the most relevant publications in the field and the main topics of interest, and to shed light on the extent to which 'indigenous' theoretical foundations and analyses (Bruton et al., 2018) have been applied to raise understanding of the specific contexts within which East Asian entrepreneurship takes place. Our intention is to offer a big picture perspective that highlights what we know and what we do not know about entrepreneurship research conducted in an East Asian setting. Following the approach of Zaheer et al. (2019), the research questions for our literature review can be stated as follows:

RQ1 how is research on East Asian new ventures developing?

RQ2 to what extent is context taken into account in studies of East Asian new ventures?

RQ3 what is the focus of studies on East Asian new ventures?

RQ4 what is the future of East Asian new venture research?

Our review of research on entrepreneurship in East Asia makes two primary contributions. First, we draw attention to areas of research in which there is a high level of contextualization, and areas where greater contextualization is likely 
to generate valuable future research opportunities. Second, we assess the degree to which various themes have been addressed in the literature on East Asian new ventures, thus enabling us to identify aspects that would benefit from greater attention.

The remainder of the paper is structured as follows. The next section describes the approach we used to carry out our literature review. In the third section, we analyze the distribution of our sampled articles by year of publication, journal and research domain, country, degree of contextualization, and type of methodology employed. The fourth section presents the findings of this review across themes. In the fifth section, these findings are discussed, and some recommendations for future research are offered. In the sixth section we elaborate on practical implications, and in the seventh section on some limitations of our review, followed by a brief conclusion.

\section{Review method}

In this paper, we report a systematic literature review of entrepreneurship research in East Asia. Specifically, we review studies on entrepreneurship in Greater China (including Mainland China; Hong Kong SAR-hereafter, Hong Kong; Macao SAR - hereafter, Macao; and Taiwan), Japan and Korea. Following recommendations by Paul and Criado (2020) and Kraus et al. (2020), we focus our review on studies published between 2000 and $2020^{1}$ in English language-based international peer-reviewed journals included in the Web of Science (WoS)/Social Science Citation Index (SSCI). Such papers can be expected to be globally accessible and meet high academic quality standards.

We first searched the WoS/SSCI database for journal articles using a combination of spatial (East Asia-related) and topical (entrepreneurship-related) keywords. Specifically, we used the following geographical keywords in our article search: China, East Asia, Hong Kong, Japan, Korea, Macao, and Taiwan. To identify entrepreneurship-specific articles, we used the following keywords: born global, business venturing, entrepreneur, entrepreneurial, entrepreneurship, new technology-based firm, new venture, and start-up. To capture all potentially relevant papers, we considered those which include at least one of the geographical and one of the topical keywords in their full text, and not only in their titles, key words and abstracts. This initial search yielded a total of 1,493 papers.

Next, we assessed the spatial and topical relevance of these papers through a review of their content. From a geographical perspective, we shortlisted papers which cover at least one East Asian country and include an explicit analysis of results related to this context. Therefore, we excluded papers which do not cover any East Asian country or which cover a large number of countries and do not offer any analysis or discussion of results that are related to specific East Asian countries. From a topical perspective, we focus on entrepreneurship in East Asian new

\footnotetext{
1 We have included articles which have been published online only until the end of 2020 . Therefore, the final, paginated versions of some articles appear in later years.
} 
120

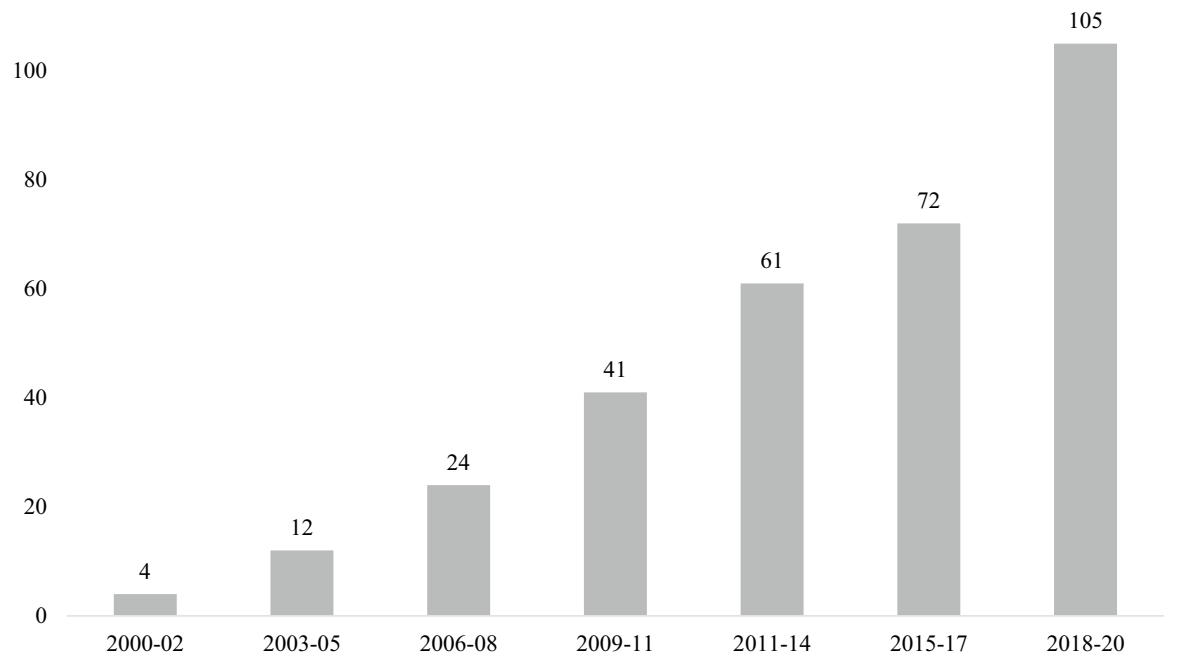

Fig. 1 Number of articles on new venture entrepreneurship in East Asia newly published by three-year periods

ventures which are designed to grow. Consequently, we removed studies on firms which are more than ten years old or which operate in industries that are not growthoriented (e.g., the catering and hospitality sectors). Furthermore, we also excluded studies on intrapreneurship and corporate entrepreneurship, as well as papers on inbound international entrepreneurship activity to our focal countries by non-East Asian entrepreneurs. Conversely, since we are interested in research on new venture entrepreneurship across different levels of analysis, we retained studies which examine the phenomenon on a regional (i.e. subnational) or ecosystem level as well as studies on individual entrepreneurs, including returnees. The relevance of each paper was assessed independently by two members of our author team, and whenever individual evaluations differed this was thoroughly discussed until agreement was reached for all papers shortlisted. This process resulted in a final sample of 319 relevant papers. A full list of papers included in our sample is provided in the data supplement.

\section{Attributes of articles on new venture entrepreneurship in East Asia}

\section{Number of articles over time and across journal domains and countries}

To answer our first research question, we analyzed the number of articles on new venture entrepreneurship in East Asia over time and across journal domains and countries. The number of articles on new venture entrepreneurship in East Asia that have been published in different years since 2000 is shown in Fig. 1. This number has steeply and steadily increased over the last two decades, indicating a rapidly 
Table 1 New venture entrepreneurship in East Asia research articles by journal domains and journals $(n=319)$

Domain/journal

Entrepreneurship

International Entrepreneurship and Management Journal

Journal of Business Venturing

Small Business Economics

International Journal of Entrepreneurial Behavior \& Research

Entrepreneurship \& Regional Development

Entrepreneurship Theory and Practice

Strategic Entrepreneurship Journal

Entrepreneurship Research Journal

Journal of Small Business Management

Other journals

Technology and innovation management

Research Policy

Technological Forecasting \& Social Change

Technovation

International Journal of Technology Management

Journal of Product Innovation Management

The Journal of Technology Transfer

Other journals

Business and management in East Asia

Asia Pacific Journal of Management

Chinese Management Studies

Asian Business \& Management

Management and Organization Review

Other journals

International business and management

Journal of International Business Studies

Journal of International Marketing

Journal of World Business

Other journals

General and other business and management journals

Journal of Business Research

Management Decision

Strategic Management Journal

Other journals

Non-business and management journals
Number of articles

$93(29 \%)$

20

12

11

11

10

9

8

5

5

2

$68(21 \%)$

14

10

7

6

5

5

21

$56(18 \%)$

18

17

8

6

7

$28(9 \%)$

8

5

5

10

$70(22 \%)$

10

10

6

44

$4(1 \%)$

Journals with less than five articles published are not individually listed 
Table 2 Composition of articles by country, territory and region $(n=319)$

\begin{tabular}{ll}
\hline Country/territory/region & Number of articles \\
\hline Single country/territory & $262(82 \%)$ \\
Greater China & $238(75 \%)$ \\
Mainland China & $213(67 \%)$ \\
Taiwan & $22(7 \%)$ \\
Hong Kong & $3(1 \%)$ \\
Japan & $13(4 \%)$ \\
Korea & $11(3 \%)$ \\
Multiple countries/territories & $57(18 \%)$ \\
Across East Asian and Non-East Asian coun- & $45(14 \%)$ \\
$\quad$ tries/territories & \\
Across countries/territories within East Asia & $12(4 \%)$ \\
\hline
\end{tabular}

expanding research interest. More than half of all articles that appeared in the last two decades were published between 2015 and 2020.

The distribution of articles across different journals and journal domains is shown in Table 1 . Within our sample, $29 \%$ of the articles are published in entrepreneurship journals, $21 \%$ in technology and innovation management journals, $18 \%$ in journals on business and management in East Asia, and 9\% in international business and management journals. Of the remainder, $22 \%$ of the articles were published in business and management journals, which do not fall into the above-mentioned domains, and $1 \%$ were published in non-business and management journals. Overall, articles on new venture entrepreneurship in East Asia are highly distributed across journals and domains, with papers published across no less than 72 journals in total.

The geographical setting of the studies reported by the sampled articles is shown in Table 2. Most studies (82\%) focus on a single country or territory, while only $18 \%$ cover multiple countries or territories. Most single country or territory studies examine new venture entrepreneurship in Greater China (including Mainland China, Taiwan and Hong Kong), with the large majority (almost 90\%) within this group focusing on Mainland China, and none on Macao. In contrast, relatively few studies focus on Japan or Korea. Most of the articles which include multiple countries compare East Asian countries or territories with countries in other parts of the world, while only twelve studies compare countries or territories within East Asia. Overall, new venture entrepreneurship research in East Asia is dominated by studies on Mainland China, and there are relatively few cross-country studies.

\section{Contextualization}

To answer our second research question, we evaluated the degree to which country-level or subnational (regional or local) spatial contextualization is provided in each article based on three categories: strong contextualization, weak contextualization, and no contextualization. Articles were considered to offer strong contextualization if such contextual issues are discussed in detail in the theory development or discussion of results sections, or both. Conversely, we classified 
Table 3 Level of country-level or regional contextualization of articles across journal domains $(n=319)$

\begin{tabular}{llll}
\hline Domain & $\begin{array}{l}\text { No contextu- } \\
\text { alization }\end{array}$ & $\begin{array}{l}\text { Weak contextu- } \\
\text { alization }\end{array}$ & $\begin{array}{l}\text { Strong } \\
\text { contextual- } \\
\text { ization }\end{array}$ \\
\hline Entrepreneurship & 28 & 27 & 38 \\
Technology and innovation management & $(30 \%)$ & $(29 \%)$ & 26 \\
Business and management in East Asia & 12 & $(38 \%)$ & 30 \\
International business and management & $(18 \%)$ & 16 & $(44 \%)$ \\
General and other business and management journals & 9 & $(29 \%)$ & 31 \\
& $(16 \%)$ & 16 & $85 \%)$ \\
Non-business and management journals & 4 & $(57 \%)$ & $(29 \%)$ \\
Total number of articles & $(14 \%)$ & 28 & 18 \\
& 3 & $(40 \%)$ & $(26 \%)$ \\
& $(75 \%)$ & $(25 \%)$ & 0 \\
\hline
\end{tabular}

articles as providing weak contextualization if the authors discuss the context of their research only briefly or in a cursory manner. Finally, articles were classified as offering no contextualization when the country-level or spatial context is not considered by the authors at all. We then assessed the degree of contextualization among our sampled papers in terms of the journal domain, country coverage, methods employed, and type of contextualization involved.

The degree of contextualization of articles published in different journal domains is reported in Table 3. Overall, $39 \%$ of the articles in our sample provide a strong contextualization, $36 \%$ a weak contextualization and $25 \%$ no contextualization. In other words, in a majority of $61 \%$ of all articles sampled, the countrylevel or spatial context of each study has not been considered at all or only briefly by the authors. From a journal domain perspective, around half of the papers published in journals that focus on business and management in East Asia provide a strong contextualization of the theory or findings, while in all other journal domains a large majority of articles provide no or only weak contextualization.

We further analyzed the type of contextualization that has been applied by researchers who consider the country-level or spatial context of their studies. Broadly following the suggestions of Welter (2011), we distinguish between articles that discuss: (i) the institutional context (such as the relative strength or weakness of formal rules and the role of informal institutions, including networks and relationships, in complementing these formal rules), (ii) the cultural context (such as values and beliefs of individuals in a given country), (iii) the policy context (such as entrepreneurship-related policies in a specific country or region), (iv) the economic context (such as the income level, economic development or market size of a country or region), and (v) multiple contexts of these types. The results are summarized in Table 4. 
Table 4 Type of country-level or regional contextualization provided by articles $(n=239)$

\begin{tabular}{llll}
\hline Type of contextualization & $\begin{array}{l}\text { Weak } \\
\text { contextual- } \\
\text { ization }\end{array}$ & $\begin{array}{l}\text { Strong } \\
\text { contextual- } \\
\text { ization }\end{array}$ & $\begin{array}{l}\text { Total } \\
\text { number of } \\
\text { articles }\end{array}$ \\
\hline Institutional & $67(50 \%)$ & $67(50 \%)$ & $134(56 \%)$ \\
Cultural & $15(38 \%)$ & $25(63 \%)$ & $40(17 \%)$ \\
Policy & $15(60 \%)$ & $10(40 \%)$ & $25(10 \%)$ \\
Economic & $10(83 \%)$ & $2(17 \%)$ & $12(5 \%)$ \\
Multiple types & $7(25 \%)$ & $21(75 \%)$ & $28(12 \%)$ \\
\hline
\end{tabular}

Table 5 Level of country-level contextualization of articles across countries and territories being covered $(n=319)$

\begin{tabular}{llll}
\hline Country/territory/region & $\begin{array}{l}\text { No contextual- } \\
\text { ization }\end{array}$ & $\begin{array}{l}\text { Weak contextual- } \\
\text { ization }\end{array}$ & $\begin{array}{l}\text { Strong } \\
\text { contextual- } \\
\text { ization }\end{array}$ \\
\hline Mainland China & 49 & 80 & 84 \\
Taiwan & $(23 \%)$ & $(38 \%)$ & $(39 \%)$ \\
& 18 & 3 & 1 \\
Hong Kong & $(82 \%)$ & $(14 \%)$ & $(4 \%)$ \\
Japan & 2 & 1 & 0 \\
& $(67 \%)$ & $(33 \%)$ & \\
Korea & 3 & 5 & 5 \\
& $(23 \%)$ & $(38 \%)$ & $(38 \%)$ \\
Across East Asian and Non-East Asian countries/ & 6 & 5 & 4 \\
territories/regions & 2 & $(45 \%)$ & $(36 \%)$ \\
Across countries/territories within East Asia & $(13 \%)$ & 16 & 23 \\
& 0 & $(36 \%)$ & $(51 \%)$ \\
& & 4 & 8 \\
\hline
\end{tabular}

A majority of $56 \%$ of all articles in which the theoretical reasoning and results are contextualized focus on the institutional context. In particular, in many studies set in Mainland China, which constitute a large majority of our sample, the weaknesses of formal institutions or institutional transition processes are discussed. Numerous scholars refer to "emerging China" or China's "transition economy" when developing their theory or making sense of their results. Another $17 \%$ of all articles which provide a country-level or spatial contextualization focus on the cultural context. In contrast, there are relatively few studies in our sample that offer contextualization related to policy-related factors (25 papers), economic factors (12 papers), or multiple contextual factors (28 papers).

We also evaluated the degree of contextualization provided by each article depending on the country or territory examined (see Table 5). A large majority of studies that focus on single countries or territories in East Asia offer no or only a weak country-level or spatial contextualization in the theory or results sections. Notably, only one study on Taiwan and none of the studies on Hong Kong provide 
Table 6 Level of country-level contextualization across methodological types of articles $(n=319)$

\begin{tabular}{lllll}
\hline Type of article & $\begin{array}{l}\text { No contextualiza- } \\
\text { tion }\end{array}$ & $\begin{array}{l}\text { Weak contextual- } \\
\text { ization }\end{array}$ & $\begin{array}{l}\text { Strong contextual- } \\
\text { ization }\end{array}$ & $\begin{array}{l}\text { Total } \\
\text { number of } \\
\text { articles }\end{array}$ \\
\hline Quantitative & 70 & 89 & 80 & 238 \\
Qualitative & $(29 \%)$ & $(37 \%)$ & $(34 \%)$ & $(75 \%)$ \\
Descriptive/narrative & 5 & 17 & 24 & 46 \\
& $(11 \%)$ & $(37 \%)$ & $(52 \%)$ & $(14 \%)$ \\
Mixed methods & 0 & 2 & 12 & 14 \\
& 5 & $(14 \%)$ & $(86 \%)$ & $(4 \%)$ \\
Theoretical/reviews & $(42 \%)$ & 5 & 2 & 12 \\
& 0 & $(42 \%)$ & $(17 \%)$ & $(4 \%)$ \\
& & $(22 \%)$ & $(78 \%)$ & 9 \\
\end{tabular}

a strong contextualization. By contrast, in a majority of comparative studies (both between East Asian and other countries or territories and within East Asia), the theory and results are strongly contextualized. One explanation for this finding is that comparative research is often conducted with the intention to delineate and better understand the differential role of contextual factors across countries.

The composition of sampled articles by methodological type and their degree of country-level or spatial contextualization across these types is shown in Table 6. We classify articles as quantitative when the research design is based on quantitative statistical methods, such as regression analysis. Articles based on case studies or the analysis of interview data are categorized as qualitative, while articles which rely on topical descriptions or narratives and do not strictly apply rigorous quantitative or qualitative methods are classified as descriptive/narrative. We also built separate categories for articles based on mixed methods and theoretical studies and reviews, with the latter category also including extended introductions to special issues of journals that reach beyond an overview of contents and offer their own detailed reasoning on the focal topics.

Three quarters of all articles sampled apply quantitative research methods and another $14 \%$ are based on qualitative methods. Relatively few articles fall into the remaining four categories. Furthermore, marked differences can be observed in the degree of country-level or subnational contextualization across the research method categories. Specifically, while only $34 \%$ of the quantitative studies and $17 \%$ of the mixed-method studies offer a strong contextualization, such contextualization is provided in the majority of qualitative, descriptive/narrative, and theoretical/review studies. These findings indicate that researchers of new venture entrepreneurship in East Asia who employ rigorous statistical methods and analysis mostly place little importance on, or take insufficient account of, spatial context in their research design, while such contextualization is more strongly supported by qualitative and descriptive methods as well as in the conceptual reasoning of theoretical and review studies. 
Table 7 Number of articles related to each theme and their degree of contextualization

\begin{tabular}{lllll}
\hline Theme & $\begin{array}{l}\text { No contextu- } \\
\text { alization }\end{array}$ & $\begin{array}{l}\text { Weak contex- } \\
\text { tualization }\end{array}$ & $\begin{array}{l}\text { Strong contex- } \\
\text { tualization }\end{array}$ & $\begin{array}{l}\text { Total number } \\
\text { of articles }\end{array}$ \\
\hline Entrepreneurial ecosystems & 8 & 33 & 37 \\
Culture & $(10 \%)$ & $(42 \%)$ & $(47 \%)$ & 78 \\
Institutions & 3 & 1 & 21 & $(84 \%)$ \\
& $(12 \%)$ & $(4 \%)$ & 48 & 25 \\
Entrepreneurial strategy & 5 & 22 & $(64 \%)$ & 75 \\
Entrepreneurial financing & $(7 \%)$ & $(29 \%)$ & 32 \\
Entrepreneurial teams & 27 & 29 & $(36 \%)$ & 89 \\
New venture internationalization & $(30 \%)$ & $(33 \%)$ & 14 \\
Entrepreneurial intention & 5 & 13 & $(44 \%)$ & 32 \\
Personal attributes of entrepreneurs & $(16 \%)$ & $(41 \%)$ & 9 & 32 \\
Networks of entrepreneurs & 17 & 6 & $(28 \%)$ & 28 \\
& $(53 \%)$ & $(19 \%)$ & 4 & $(14 \%)$ \\
& $(32 \%)$ & $(54 \%)$ & 6 & 22 \\
\hline
\end{tabular}

The number of articles across all themes exceeds the number of reviewed articles, as many articles are related to more than one theme

\section{Thematic analysis of new venture entrepreneurship research in East Asia}

To answer our third research question, we analyzed the contents and findings of our sampled articles across research themes and levels of analysis. Using an inductive process of reviewing keywords and themes, the research team identified ten themes that broadly follow those identified by Meyer et al. (2014) and by Lopez and Alvarez (2018) in a comparable study of Latin American entrepreneurship: entrepreneurial ecosystems, culture, institutions, entrepreneurial strategy, entrepreneurial financing, entrepreneurial teams, new venture internationalization, entrepreneurial intention, personal attributes of entrepreneurs, and networks of entrepreneurs. While most of our themes are also recognized by Meyer et al. (2014) and Lopez and Alvarez (2018), this is not the case for entrepreneurial teams, which thus appears to have emerged as a recent theme in new venture entrepreneurship research, at least in an East Asian setting. Furthermore, while Meyer et al. (2014) and Lopez and Alvarez (2018) exclusively focus on entrepreneurial orientation within the realm of entrepreneurial strategies, we have also found studies on other aspects of new venture strategies, including effectuation, resource utilization and market orientation, and have therefore categorized them under the overarching theme of entrepreneurial strategy.

The number of articles which are related to each theme and their degree of contextualization are reported in Table 7. While the themes of entrepreneurial 
ecosystems, institutions, entrepreneurial strategy, and personal attributes and networks of entrepreneurs have been studied intensively in our sample, the remaining five themes have received much lower research attention. Furthermore, the majority of papers related to the themes of culture and institutions (84\% and 64\%, respectively) are strongly contextualized, while most articles relating to the remaining themes offer only a weak or no contextualization. Most notably, 53\% of all studies on entrepreneurial teams have not been contextualized at all.

We now summarize our theme-related observations of new venture entrepreneurship research across three levels of analysis: (1) the systemic and contextual level (including the themes of entrepreneurial ecosystems, culture and institutions), (2) the firm- and team-level (including the themes of entrepreneurial strategy, entrepreneurial financing, entrepreneurial teams and new venture internationalization), and (3) the individual level (including the themes of entrepreneurial intention, personal attributes, and networks of entrepreneurs). Studies that report important findings related to a given theme are selectively cited.

\section{Systemic and contextual level research}

\section{Entrepreneurial ecosystems}

Many papers in our sample contribute to an understanding of how national, regional and local conditions shape the level, quality and performance of entrepreneurial activity in East Asia. Researchers have investigated national context factors, the dynamics of regional agglomerations, and the roles of science parks, incubators and universities in the development of entrepreneurial ecosystems that promote the establishment and growth of new ventures. Among these articles, most papers are single country studies, with Mainland China (hereafter: China) featuring most prominently. Only one study (Hemmert et al., 2019) has examined entrepreneurial ecosystems across the East Asian countries, identifying the conditions that are conducive to new venture entrepreneurship in major agglomerations and the active role played by national, regional and local government bodies.

A number of studies explain how national contextual factors in East Asia influence entrepreneurial motivation, perceptions of risks and opportunities, as well as expectations about support infrastructures. An early study of Japanese entrepreneurs found that they feel less supported by professional services, universities and venture capitalists compared with counterparts in the USA, while receiving more bank loans and public funding (Suzuki et al., 2002). The lack of private support infrastructure is also visible in other East Asian countries, especially China, where it can be attributed to the country's stage of development. As a consequence, government involvement has been more prevalent (Chen et al., 2020). Conversely, in a mature economy like Japan these shortcomings reflect characteristics of the innovation system, where intrapreneurship in the commercialization of new technologies is more prominent than entrepreneurship. For example, most of the research and development (R\&D) that created Japan's service robot industry was performed by large companies (Lechevalier et al., 2014). Similarly, 
entrepreneurs in Japan's biopharmaceutical industry tended to have worked previously in large companies rather than public or university research institutes (Jolivet et al., 2009). A study of Korea's entrepreneurial ecosystem identified weak private support infrastructure and unsupportive immigration policies as major challenges (Kshetri, 2014).

At the subnational level, start-up activity in East Asia is mainly driven by access to human capital, technology and agglomeration effects (Li, 2017). Quantitative studies show significant knowledge spillover effects and positive feedback cycles whereby regions with strong business clusters and a strong entrepreneurial activity base create favorable conditions for East Asian start-ups (e.g., Yu, 2020). One qualitative study recounts the city of Kyoto's success in leveraging its strong knowledge base in medical devices to establish a vibrant life science cluster by linking its strong and internationally connected research infrastructure with local stakeholders from politics, business and finance (Ibata-Arens, 2009).

The policy-driven nature of entrepreneurial ecosystems in East Asia is most visible in the rapid development of science parks and incubators. It is estimated that China had established around 10,000 science parks by 2020 (Chen et al., 2020). Science parks support skills and reputation building, and help promising new ventures to be identified and supported (Armanios et al., 2017). They also provide important human management resource services (Motohashi, 2013). Technology-intensive start-ups in particular are able to benefit from a combination of interaction, synergy and agglomeration effects associated with such policy initiatives (Xie et al., 2018). Whereas early studies suggest that technology-intensive new ventures located outside of science parks are more efficient in commercializing technology (WatkinsMathys \& Foster, 2006), later studies show that science park-based start-ups have a higher R\&D efficiency (Yang et al., 2009), because the location has helped new ventures to upgrade their business models over time, adding more services along the value chain (Tang et al. 2021). Recent studies also show that the business models, strategies and performance of Chinese new ventures continue to be strongly influenced by the socio-economic development of the regions or cities in which they are located (Xiao \& North, 2017; Zhou et al., 2020). A study on technology incubators in Taiwan argues that government-supported incubator programs need to be more demand-oriented and should be run by private management teams ( $\mathrm{Ng}$ et al., 2019). Furthermore, early surveys of Taiwanese and Korean start-ups suggest that the services provided by science parks and incubators are not decisive success factors for the establishment and growth of new venture businesses (Li \& Chen, 2009; Sung et al., 2003).

Studies on entrepreneurial ecosystems in China, Hong Kong, Korea and Taiwan also highlight the important role that universities play in technology-intensive startup ecosystems by nurturing prospective entrepreneurs (Choi et al., 2017; Wong et al., 2019) and by contributing to the transfer and commercialization of technologies through joint research, university spin-offs or direct engagement as incubators (Li et al., 2019). At the same time, studies on university-industry cooperation in China and Korea have found that government involvement can negatively impact new venture performance because of overly restrictive regulations or imperfect incentive structures (Jung \& Kim, 2018; Kroll \& Liefner, 2008). 
Overall, while many studies examine the national and sub-national context of entrepreneurial activity in East Asia, they do not apply entrepreneurial ecosystem frameworks in a stringent way, with the exception of Hemmert et al. (2019). This can partly be explained by the fact that most papers do not cover all ecosystem dimensions, but tend to limit themselves to selected sub-sets of environmental factors.

\section{Culture}

Several cross-country studies have examined how cultural factors influence East Asian new venture entrepreneurs. For example, Kawakami et al. (2012) found that the use of market information in new ventures in China and Japan differs from that in the USA, and link these differences to cultural factors, such as high levels of collectivism. Similarly, in a study on entrepreneurial intentions in Taiwan and Spain, Liñán and Chen (2009) found cross-country differences in the relative importance of subjective norms and attributed them to cultural factors, including individualismcollectivism and uncertainty avoidance. Furthermore, a study on entrepreneurial intentions in China and Hong Kong revealed that the relation between perceived social norms and entrepreneurial intention depends on the degree to which potential entrepreneurs value their connectedness with others (Siu \& Lo, 2013). In a study of five countries including China, national culture and cultural orientation of entrepreneurs have both been found to influence variance in the innovation-growth relationship (Rauch et al., 2013).

Culture has also been found to influence entrepreneurial activities, with most research being focused on China. Cultural characteristics that emphasize harmony, face, and understanding have been found to result in a negative effect of extraversion on perceived career achievement in China (Lau et al., 2007). Furthermore, the family, social, and institutional context of China have also been found to positively influence the performance of Chinese new ventures (Lin et al., 2015). For example, Buddhism, which is widely influential in East Asia, has been argued to shape the entrepreneurial risk-taking strategies of Chinese entrepreneurs (Liu et al., 2019b) while, in a case study on a Korean new venture, cultural features such as an emphasis on harmonious inter-personal relations and high levels of patriotism have been identified as a constraining factor in the firm's rapid and early internationalization (Zhang \& Dodgson, 2007). Conversely, Lam (2010) identified supportive local enterprise culture in Hong Kong and Shanghai as a factor which drives individuals towards entrepreneurship.

Zhong-Yong thinking (a cognitive style whereby individuals consider issues from different perspectives, avoid going to extremes, behave in situationally appropriate ways, and maintain harmony) has been found to enhance new venture performance (Ma et al., 2018). Other studies have examined the influence of culturally embedded guanxi networks in China. For example, Lau et al. (2012) found that the capability to build and maintain indigenous guanxi networks is a condition for the success of Chinese entrepreneurs. However, social networks in China have also been found to result in gender discrimination against female entrepreneurs (Xie \& Lv, 2016).

Another group of studies has examined cultural transformations over time and subnational cultural differences in new venture entrepreneurship in East Asia. Li 
et al. (2012b) observe that different ethnic communities in China have different entrepreneurial cultures. Furthermore, cultural gaps between science and business have been found to diminish the effectiveness of science and technology policies in Japan (Eto, 2005).

Overall, cultural features exhibit a mixed influence on new venture entrepreneurship in East Asia. For example, while collectivism may help entrepreneurs with finding supporters by leveraging their networks, it may also inhibit entrepreneurial behaviors such as risk taking.

\section{Institutions}

The institutional settings of East Asia are distinct from those in North America and Europe, and so are the entrepreneurs (Bruton et al., 2009). Ahlstrom and Bruton (2006) suggest that entrepreneurial actors in East Asia have been subject to a changing institutional environment caused by economic transition processes.

Institutional transitions, in particular the strengthening of formal institutions, such as capital markets, labor markets, and supportive regulations and policies have been observed to influence new venture entrepreneurship in China. For example, access to finance has been found to influence start-up agglomerations in China (Pan \& Yang, 2019). Yang and Wang (2013) found that various stakeholders achieved the institutionalization of electronic marketplaces in China through interwoven diffusion and legitimization processes. Chinese entrepreneurs have utilized intermediaries (Armanios et al., 2017) and political connections (Ge et al., 2017) to bridge institutional voids. Further, due to ongoing institutional transition, competing institutional logics co-exist; and entrepreneurs adopt different responses to these institutional settings (Zhang et al., 2016).

The impact of formal and informal institutions on new ventures in China has been found to be moderated by various factors. Relational trust (Bauke et al., 2016), adaptive capability (Lu et al., 2010), ties with service intermediaries (Zhang \& Li, 2010), public-private hybrid forms (Zhou, 2017), and legitimacy-based strategies (Zhang $\&$ White, 2016) have each been found to complement the impact of national-level institutional characteristics. The psychological characteristics of entrepreneurs may also influence the way institutions influence their decision-making, as they view institutional arrangements from their individual perspectives (Jiang et al., 2018; Lu $\&$ Tao, 2010).

Due to institutional transitions, Chinese entrepreneurs exhibit specific strategic mindsets such as aggressive, analytical, and risk-taking orientations (Lau \& Bruton, 2011), and engage in inter-firm alliances (Li \& Atuahene-Gima, 2002) and international entrepreneurship (Khavul et al., 2010b). The institutional environment has been found to influence the behavior of venture capital firms (Zacharakis et al., 2007), angel investors (Ding et al., 2014), universities (Eun et al., 2006), and returnee entrepreneurs (Gruenhagen 2019) in various ways. Furthermore, entrepreneurs from the informal economy have been found to drive institutional change (Lee \& Hung, 2014).

Another stream of research has examined the role of government in promoting entrepreneurship in China. Entrepreneurial support policies have been found 
to facilitate the creation of industry clusters (Liu et al., 2013), encourage female entrepreneurs (Xie \& Lv, 2018), support incubators (Tang et al., 2014), and provide legitimacy through $\mathrm{R} \& \mathrm{D}$ subsidies ( $\mathrm{Li}$ et al., 2018) or equity ownership (Wang et al., 2018). The Chinese government has also been found to support university spin-offs in commercializing innovations (Kroll \& Liefner, 2008), inviting foreign investment (Pereira, 2004), and offering reduced corporate tax rates (Liu et al., 2019a). Similarly, interventionist industrial policies were influential in promoting global expansion of the Korean online gaming industry (Casson \& Park, 2014) and the rise of Taiwanese technology-based industries (Hung \& Chu, 2006). These policy measures have been generally found to be effective in promoting new venture entrepreneurship.

In comparison to China, fewer studies have been conducted in East Asian countries with more developed institutions, such as Korea and Japan. Ibata-Arens (2009) found that developed institutions in Japan may positively influence entrepreneurial activities through social networks, while Lechevalier et al. (2014) studied the emergence of new industries in Japan as a result of collaborations between entrepreneurial firms and established large firms. Other studies have examined the promotion of new venture entrepreneurship through policy changes in Japan (Eberhart et al., 2017) and in Korea (Kshetri, 2014).

\section{Firm-level and team-level research}

\section{Entrepreneurial strategy}

Entrepreneurial strategies of new ventures in East Asia have been intensively researched, and a large majority of studies on entrepreneurial strategy have focused on China.

Although many entrepreneurial activities are generally resource-constrained, studies in our sample argue that China poses particular challenges to entrepreneurial firms due to resource scarcity and less developed markets. In this context, government or political ties have been found to be important for overcoming resource constraints in China because the government still has considerable power to approve development projects and allocate important resources such as land and energy (e.g., Li \& Zhang, 2007). Furthermore, effectuation approaches to entrepreneurship based on goal selection within a given set of means have been examined intensively in the China context. The effectuation approach is found to have a positive influence on various outcomes, such as opportunity identification (Guo et al., 2020) and new venture performance (Cai et al., 2017b). However, for an effectuation approach to play an effective role, new ventures need to engage in exploratory learning (Cai et al., 2014, 2017b).

Some authors have highlighted the volatile and dynamic nature of China's technological and commercial environment, such that new ventures are compelled to access and exploit external sources of technology (e.g., Cai et al., 2014). Access to heterogeneous knowledge sources in order to increase new ventures' knowledge 
recognition capabilities has been found to play a critical role in enhancing innovation performance (e.g., Fang et al., 2017).

A different stream of research has examined how East Asian entrepreneurs develop the capabilities and strategies to use their resources. There is little doubt that capabilities and strategies to utilize resources are central to the success of entrepreneurial firms (e.g., Guo et al., 2020). However, due to different resource endowments across East Asian countries, different organizational capabilities are emphasized in the literature. For example, in Korea, the adaptive capabilities of new ventures are highlighted as helping firms recognize changes in market expectations and uncovering new opportunities as new resources are acquired, along with the knowledge of how to use and recombine those resources (Eshima \& Anderson, 2017). In China, the role of the relationship between learning capabilities and resource acquisition has been found to be more critical (e.g., Cai et al., 2014).

Furthermore, a close alignment of resource utilization, learning and adaptive capabilities with strategic orientation (i.e., entrepreneurial orientation and market orientation) has been identified as a performance antecedent for new ventures. $\mathrm{Mu}$ and Di Benedetto (2011) suggest that learning capabilities are a mediator between market orientation and new venture performance. Other studies report that adaptative capabilities mediate the positive link between resources and performance (Lu et al., 2010) and between firm growth and entrepreneurial behavior and risk-taking (Eshima \& Anderson, 2017).

Innovation is one of the most intensively studied entrepreneurial activities in the China context. Technology-intensive new ventures are required to systemically integrate resources and knowledge to efficiently manage a variety of product innovations required in this large emerging market (Guo et al., 2019). Environmental dynamism, entrepreneurial leadership and ethical leadership are also crucial for innovation activities and new venture performance (Mai et al., 2019).

With respect to competition, China is characterized as having underdeveloped formal market institutions and, as a consequence, dysfunctional competition (Du et al., 2016). Mixed evidence on the outcomes of dysfunctional competition indicate that its impact is contingent on strategic settings. While some authors argue that dysfunctional competition has a negative impact on innovation strategies and new venture performance (e.g., Cai et al., 2017b), other studies have found that it can positively moderate the relationship between innovation strategy and competitive advantage in the early stages of new venture formation and growth (e.g., Cai et al., 2017a).

\section{Entrepreneurial financing}

The focus of sampled papers belonging to the theme of entrepreneurial financing is generally on factors that influence the probability of start-ups obtaining external funding, particularly private equity financing (i.e., angel investment, venture capital, crowdfunding and accelerators). Some studies explore the investment decision process of equity investors, while others investigate the outcomes of financing. Most papers examine entrepreneurial financing in China. 
Various antecedents of financial support from investors have been identified from three perspectives, namely the entrepreneur, investor, and organizational perspectives. From the entrepreneur perspective, entrepreneur attributes and characteristics have been investigated the most. For instance, Batjargal and Liu (2004) show that the social capital of entrepreneurs is positively related to the investment decision of venture capitalists (VCs) and that strong network ties among entrepreneurs and venture capital firms influence the investment process decisions of VCs, and help new venture entrepreneurs to secure private equity and obtain higher valuations of their firms.

From the investor perspective, studies explore how investors, especially private equity investors, evaluate the quality of ventures and make investment decisions. For instance, Zacharakis et al. (2007) found that in comparison with their counterparts in the USA, VCs in Korea and China rely to a higher extent upon the entrepreneur's human capital when making investment decisions. Wang (2016) examines the role of social networks in supporting entrepreneurial firms' VC financing acquisitions and finds that entrepreneurial firms are more likely to obtain interview offers and funding from VCs with whom they have social ties.

From an organizational perspective, several studies investigate the effect of firm endorsement factors on funding decisions. For example, Ding et al. (2014) show that Chinese angel investors tend to rely on strong endorsement ties such as family and friends in the management team when making investment decisions. Li et al. (2019) suggest that obtaining government R\&D subsidies can be used as a legitimation strategy for innovative entrepreneurial firms to access and acquire financial support from banks.

The sampled studies also examine the nature of financing available. Various types of financial support are investigated, including government funds, family funds, crowdfunding, equity financing and bank loans (e.g., Li et al., 2019; Wang et al., 2017). Other studies consider the national financing system holistically. For example, White et al. (2005) proposed a financing system framework which can be defined as the country-specific configuration of actors, rules and practices through which investment funds are pooled, investment targets identified, funds invested and monitored, and returns appropriated.

Finally, some studies investigate the effects of financing on entrepreneurial firm performance, including types of entrepreneurship, start-up performance and innovation. For example, Ni et al. (2014) report that VC financing generates positive but limited effects on entrepreneurial innovation. Similarly, based on a study of the Chinese Innofund program, a governmental initiative intended to support small and medium-sized technology firms, Wang et al. (2017) showed that entrepreneurial firms which received high project evaluation scores and Innofund grants subsequently performed better than those that did not.

\section{Entrepreneurial teams}

Studies on new venture teams in East Asia generally cover three topics: (1) team composition, (2) team capabilities and processes, and (3) the impact of these capabilities and processes on organizational outcomes and performance. The 
extant research predominantly focuses on entrepreneurial teams in Chinese new ventures.

Studies on team composition tend to highlight heterogeneity issues. Researchers have examined teams' functional, educational, age, and tenure heterogeneity and their various impacts on new ventures. Xu et al. (2017) found that initial public offering (IPO) prices are negatively affected by new venture teams' functional and age heterogeneity, but positively affected by educational heterogeneity. Xie et al. (2020) observe that team power hierarchy positively effects new venture performance when team members have homogenous functional backgrounds, but has a negative performance effect for teams with heterogenous functional backgrounds.

Studies on team capabilities in general focus on team cognition, experience and social networks. Zhao et al. (2015) report that the start-up experience of the founding team enhances market resource acquisition which in turn accelerates new product launches. Zheng (2012) finds that the prior shared experience of the founding team can help build transactive memory (representing teams' shared cognition) and enhance new venture performance. Dai et al. (2016) further suggest that teams' transactive memory systems strengthens their entrepreneurial orientation. There is also evidence showing that team experiences can affect firms' management behaviors such as human resource management (HRM) practices. Khavul et al. (2010a) found that firms led by Chief Executive Officers (CEOs) who possess general management experience invest more in strengthening HRM practices. Furthermore, ethical awareness among top management teams has been found to enhance product innovation (Mai et al., 2019).

The scope of studies that examine team processes is relatively wide. Specifically, it has been found that a shared team vision enhances internal and external integration (Chen, 2015), that conflict negatively affects team performance (Li et al., 2020), and that trust augments team performance and new venture competitiveness $(\mathrm{Wu}$ et al., 2009). It has also been found that routines have mixed effects upon team performance (Lin et al., 2017), that learning enhances firms' competitive advantage (Xiong, 2020), and that information exchange within new venture teams strengthens innovation performance (Liu et al., 2015).

When measuring outcomes, studies tend to consider firm behavior and performance. The three major behavioral outcomes studied are innovation (Liu et al., 2015; Mai et al., 2019), strategic decision making (Li \& Li, 2009) and management practices (Khavul et al., 2010a). The most commonly employed performance outcomes investigated include economic performance such as IPO pricings (e.g., Wang et al., 2018), financial performance (Guo et al., 2019) and the competitive advantages of new ventures (Wu et al., 2009; Xiong, 2020). Notably, most of the studies within this sub-theme are cross-level; that is, they mainly discuss the influence of team behaviors at an organizational level. In contrast, there are comparatively few articles that discuss outcomes at the team level.

Finally, team members' personality attributes have also been studied as an antecedent of entrepreneurial team performance. For example, Zhou (2016) found that shared leadership improves entrepreneurial team performance depending on the level of 
diversity of individual members' personalities. Overall, however, the composition of entrepreneurial teams in East Asia has not attracted much research attention.

\section{New venture internationalization}

Relatively few studies specifically examine the issue of new venture internationalization, with most articles concentrating on Chinese firms. As regards the speed of internationalization, Zou and Ghauri (2010) found that the internationalization of Chinese new ventures progresses gradually, but often starts with entries into culturally dissimilar Western countries to acquire knowledge and technologies. With regards to the timing of internationalization, Zhou and $\mathrm{Wu}$ (2014) observe that early internationalization enhances the performance of Chinese new ventures.

The internationalization of East Asian start-ups has been shown to be influenced by various factors. Entrepreneurial strategic posture positively influences the international learning efforts and thereby the international performance of Chinese new ventures (De Clercq \& Zhou, 2014). The desire to enhance domestic reputation, to exploit stocks of prior knowledge, and to explore the benefits of incoming knowledge flows also drives Chinese start-ups to internationalize (Yamakawa et al., 2013).

Access to knowledge has been identified as another key antecedent of new venture internationalization. Education backgrounds of the CEO influence the choice between international and Chinese domestic IPOs (Bai et al., 2020), while adaptive capability (the ability to coordinate, recombine, and allocate resources) and stronger HRM development have been found to accelerate the internationalization of Chinese new ventures by Lu et al. (2010) and Khavul et al. (2010a), respectively.

Learning from customers has also been found to be important for the internationalization outcomes of new ventures. Su (2013) observes that Chinese new ventures combine strategic planning and resource acquisition with flexible adjustment in response to existing customer relationships. On the other hand, Williams et al. (2020) report that domestic online social networking sites, rather than foreign ones, help Chinese internet firms to be more internationally oriented.

As regards external factors, Murmann et al. (2015) find that the size of home market demand is negatively related to the likelihood of developing international partnerships, with Taiwanese new ventures showing a higher propensity to establish such partnerships than their Japanese counterparts. Within-country differences are also discussed in the literature. The presence of foreign firms, especially when institutional development is strong, positively influences new venture internationalization in China (Fernhaber et al., 2019). Conversely, Marquis and Qiao (2020) find that the degree of communist ideological imprint of Chinese new venture entrepreneurs is negatively related to their firms' internationalization. 


\section{Individual-level research}

\section{Entrepreneurial intention}

New venture entrepreneurial intention in East Asia has been studied to a modest extent. Some studies focus on entrepreneurs' personal characteristics and personality traits. For example, Chang et al. (2014) found that personal motivation, attitude, subjective norms and perceived behavioral control generate positive effects on entrepreneurial intentions in China. Furthermore, Lu and Tao (2010) observe that personal Chinese communist party affiliation and public ownership status influence entrepreneurial intentions. Specifically, higher public-ownership status discourages entrepreneurial intention. More recent studies examine the effects of personality traits on entrepreneurial intention. For example, Munir et al. (2019) found that risktaking propensity, locus of control and proactive personality are positively related to entrepreneurial intention. Shahab et al. (2019) found that entrepreneurial selfefficacy positively influences entrepreneurial intention in Korea. Similarly, Yu et al. (2020) report a positive relationship between entrepreneurs' creativity and social entrepreneurship intentions in China.

In other studies, the focus is not on the background of entrepreneurs, but on external factors including entrepreneurial financial and family support and the institutional environment. For example, Choi et al. (2017) found that entrepreneurshiprelated financial support provided by universities increases the number of student founders in Korea. Similarly, Lin and Wang (2019) suggest that family support has a positive effect on the re-venture speed of serial entrepreneurs in China.

Multiple moderators and mediators to these antecedents have advanced understanding and added considerable extensions to the entrepreneurial intention literature. For example, Shahab et al. (2019) found that attitudes towards entrepreneurship and entrepreneurial education positively moderate the relationship between entrepreneurial self-efficacy and entrepreneurial intention. Similarly, Lin and Wang (2019) report that the relationship between the age of an entrepreneur and re-venture speed is strengthened by failure loss, but weakened by family support.

A few studies have also discussed the performance outcomes of entrepreneurial intention in East Asia. For example, Jin (2017) suggests that young entrepreneurs' entrepreneurial intention is positively associated with entrepreneurial firms' financial and non-financial performance. Similarly, in a study of university graduates from China, Yi (2021) found that entrepreneurial support by universities and external policy support help turning green entrepreneurial intention into green entrepreneurial behaviors.

\section{Personal attributes of entrepreneurs}

Studies conducted at the level of individual new venture entrepreneurs in East Asia have mainly focused on personal traits, international exposure, gender, and human capital. Again, most of the studies in our sample are set in China. The research draws on major theories such as the resource-based view, the knowledge-based view, upper 
echelon theory, and social network and social capital theory to help explain how personality traits of entrepreneurs influence new venture outcomes.

Lin and Wang (2019) investigate how the age of serial entrepreneurs' impact reventure speed after a business failure and find that older entrepreneurs take longer to re-start a venture than younger entrepreneurs. Li et al. (2020) found that CEO humility is able to reduce relationship conflict in entrepreneurial teams and enhances the performance of new ventures. Mai et al. (2019) examine outcomes of Chinese entrepreneurs' moral awareness and ethical behavior and find that while low levels of moral awareness are positively associated with individual creativity, entrepreneurs with high levels of ethical behavior have the capacity to establish more creative founding teams.

The gender of East Asian new venture entrepreneurs has received increased research attention. In particular, while East Asian societies have traditionally been male-dominated, some studies on female entrepreneurs have been conducted in recent years. $\mathrm{Ng}$ et al. (2016) identify feminine entrepreneurial characteristics, such as being personally supportive towards customers, as an important success factor for Chinese female entrepreneurs who use social networks as a platform for their business. Zhao et al. (2020) report that female Chinese entrepreneurs are more likely to be funded through equity crowdfunding than their male counterparts.

The human capital of Chinese new venture entrepreneurs, understood as their skills, knowledge, and experience, has been found to have a positive influence on new venture performance (Huang et al., 2012) and innovation (Li et al., 2018).

Lastly, Chinese returnee entrepreneurs have been studied to a considerable extent. Various studies have reported that Chinese new ventures which are founded by returnee entrepreneurs outperform their local rivals due to the returnees' superior knowledge and networks (e.g., Bai et al., 2019; Filatotchev et al., 2011). However, other studies have shown that returnee entrepreneurs incur liabilities of foreignness (Li et al., 2012a) which impede their entrepreneurial activities in China (Qin et al., 2017).

Overall, East Asian new venture entrepreneurs' personal attributes have been quite intensively studied, and certain aspects, including entrepreneurs' human capital and international exposure, have been identified as important resources for positive entrepreneurial outcomes.

\section{Networks of entrepreneurs}

Studies on the networks of new venture entrepreneurs in East Asia have focused primarily on the Chinese context. Therefore, entrepreneurs' networks are predominantly conceptualized as guanxi ties, which are seen as central to understanding entrepreneurship in China (Huang et al., 2012).

Many studies investigate the relationship between entrepreneur ties (i.e. networks) and organizational innovation or performance. Batjargal et al. (2013) found that the positive performance effect of networks' structural holes is stronger in an environment with weaker and more inefficient institutions. Li and Zhang (2007) observe a positive association between new venture entrepreneurs' political networking and functional experience and new venture performance. Various studies differentiate 
between the business ties and political ties of Chinese new venture entrepreneurs and examine their performance implications. While Lin et al. (2014) found that political ties have a positive performance effect whereas business ties do not, both types of tie have been observed by Shan and Lu (2020) to enhance entrepreneurial knowledge acquisition.

Some studies also highlight the dark side of developing government or political connections. For example, Su et al. (2015) report that political networking in China weakens the positive linkage between entrepreneurial orientation and new venture performance while, in a recent paper, Luo et al. (2020) reveal that political relationship building by Chinese new ventures can be an obstacle for customer acquisition because of concerns about certainty of payments and levels of control.

Zhang et al. (2016) have studied changes of entrepreneurs' political networking over time and found that more recent Chinese entrepreneurs built fewer political networks compared to entrepreneurs that started earlier, and that the focus of networking behavior has shifted from the establishment of ties with bureaucrats towards the management of such ties.

Overall, while many studies have found guanxi ties to be instrumental for new venture entrepreneurship in China, recent studies have emphasized the potential negative side effects of political ties.

\section{Discussion and future research directions}

To answer our fourth and final research question, we now discuss our overall findings and offer directions for future research on new venture entrepreneurship in East Asia. Various findings emerge from our systematic literature review. First, the number of articles which are related to new venture entrepreneurship in East Asia has steeply increased throughout the last two decades. While research interest in entrepreneurship in other parts of the world (e.g., Lopez \& Alvarez, 2018) and on other emerging topics in entrepreneurship studies (e.g., Hayter et al., 2018; Zaheer et al., 2019) has also increased, the growth of the number of articles on these topics is not nearly as strong as on new venture entrepreneurship in East Asia. As a result of more intensive research in recent years, the amount of knowledge on East Asian new ventures has rapidly expanded. While most new venture business and management research is still focused on Western countries, a clearer picture has developed on the business environment, activities and outcomes of new venture entrepreneurship in East Asia. This heightened research attention is timely in view of the rapidly increasing importance of East Asian new ventures in global business.

Second, notwithstanding the rapidly increasing number of articles, we find that research on new venture entrepreneurship in East Asia is highly unbalanced. From a spatial perspective, no less than $75 \%$ of all the articles sampled study new venture entrepreneurship in Greater China, while there are relatively few articles on new venture entrepreneurship in Japan and Korea. More research on Japanese and Korean new ventures is highly desirable in view of the vibrant activities of start-ups from the two countries in recent years (Hemmert et al., 2019). For example, while Chinese new venture entrepreneurs' networks have been extensively studied, little 
is known about the networks of their Japanese and Korean counterparts. Furthermore, while $82 \%$ of all studies focus on new ventures within one country or territory, only $4 \%$ of all articles compare aspects of new venture entrepreneurship across East Asian countries or territories. In view of the cultural commonalities (Gupta \& Hanges, 2004) and institutional and economic heterogeneity (Beeson, 2014) across East Asia, there is clearly a potential to advance our knowledge on new venture entrepreneurship through more comparative studies between East Asian countries.

From a methodological perspective, $75 \%$ of all sampled articles solely rely on quantitative analysis. While this predominance reflects a general preference for quantitative analysis in business and management studies (Bryman, 2011), the low number of qualitative studies on new venture entrepreneurship in East Asia nonetheless seems problematic. Since entrepreneurship is a process and should be studied as such (Kuratko \& Morris, 2018), more qualitative studies are needed to generate new insights in the field of entrepreneurship. Moreover, whereas quantitative methodologies are suitable for testing established theories and constructs, qualitative studies can help with identifying new phenomena in different contexts (including over time) when studying new venture entrepreneurship in East Asia. Greater use of qualitative research designs, which allow for contextualization more easily than do quantitative studies, can facilitate a deeper understanding of contextual dimensions in future new venture entrepreneurship research in East Asia.

From a topical perspective, research attention on new venture entrepreneurship in East Asia has been very uneven as well. While some themes, such as entrepreneurial strategy, have been intensively studied, other important topics have been examined much less. Specifically, we found a relatively low number of articles on culture, entrepreneurial finance, entrepreneurial teams, international entrepreneurship, and entrepreneurial intention (Table 7). A topic that has been examined particularly sparsely concerns the human capital of East Asian entrepreneurs, which is a sub-theme of personal attributes of entrepreneurs. While entrepreneurs' networks, including guanxi ties in the Chinese context, have been extensively studied, relatively little is known about how education and experience of East Asian new venture entrepreneurs shape their entrepreneurial activities and outcomes. This is surprising, not least because the human capital of entrepreneurs in this region appears to be particularly critical for their success due to Confucian cultural traditions (Hemmert \& Kim, 2021). Another important topic which has received increasing, but still relatively limited, research attention is female new venture entrepreneurship in East Asia. While business in East Asian countries has been traditionally male-dominated, the role of female new venture entrepreneurs clearly has become more important, and research suggests that their entrepreneurial behavior is different from that of their male counterparts ( $\mathrm{Ng}$ et al., 2016). However, there is still a limited understanding of the development and characteristics of female new venture entrepreneurship in East Asia. Thus, more research on such understudied yet important topics is needed.

Third, only $39 \%$ of our sampled studies provide a strong country-level contextualization and we found a large number of studies that do not consider the East Asian context at all, notwithstanding the major contextual differences with Western countries. A theme where the level of contextualization is particularly 
low is entrepreneurial teams. Few studies have examined the team structure (including social relationships, capabilities and power of team members) and team development (including team building, new additions and exit) as well as whether and how they are different from new venture teams in Western countries. For example, the Western literature highlights the importance of friendship among team members (e.g., Francis \& Sandberg, 2000), but is this also true in the East Asian context? Also, studies in organizational behaviors emphasize that East Asian firms usually demonstrate some distinct leadership styles and leadership roles (Hemmert, 2020; Wang et al., 2012) so, in entrepreneurial teams, will these distinctive leadership styles, such as paternalistic leadership, help new ventures to improve performance outcomes more effectively? None of these questions has been thoroughly studied so far. Furthermore, most studies on individuals' intention to found new ventures also have not given much attention to context. Little is known about how the cultural context (such as the attitudes of nascent entrepreneurs, their families and friends, and gender-specific role models), the institutional context (such as the strength and stability of norms, rules, and government policies) and the evolving business and economic environment (such as the role of e-commerce platforms and social media) are shaping entrepreneurial intentions in East Asia.

The low degree of contextualization of a large part of new venture entrepreneurship research in East Asia could be due to a tendency in academia to appreciate and value a high degree of external validity. Leading business and management journals emphasize general theory building (Tourish, 2020), while context-specific contributions are less valued (Delios, 2017). As a result, many researchers may have been induced to present their findings in a general manner, with no or limited consideration of the context of their studies. However, as our review has found, new venture entrepreneurship is strongly influenced by various contextual factors, such as institutions and culture. Therefore, more contextualization is desirable in future entrepreneurship research, as the institutional, cultural, political and economic context of East Asia is very different from the Western countries where entrepreneurship research originated.

Finally, from a theoretical perspective, while we found that many studies on East Asian new venture entrepreneurship have strong theoretical foundations, the underlying theories overwhelmingly derive from Western research. For example, various studies refer to entrepreneurial ecosystems, effectuation, entrepreneurial orientation, team cognition, and entrepreneurs' personality traits and social capital-concepts which were initially established in the West. In contrast, few studies consider or discuss to what extent these concepts fit with new venture entrepreneurship in East Asia or need to be adapted or refined in some way. Moreover, aside from the conceptualization of personal ties as guanxi in the Chinese context (e.g., Lau et al., 2012) and a few studies on Buddhism and indigenous concepts such as Zhong-Yong thinking (e.g., Ma et al., 2018), we did not find many studies which directly engaged with indigenous theorizing on East Asian new venture entrepreneurship research. Notably, such indigenous research appears to be entirely absent in English-language publications on entrepreneurship in Japan and Korea. In the future, more indigenous theory building should be valuable to elevate our understanding of when, how and 
why entrepreneurship happens and who becomes involved in new venture creation and growth in East Asia.

\section{Practical implications}

From a managerial perspective, our findings indicate that in addition to entrepreneurial orientation, the importance of which has been emphasized in Western research on entrepreneurial strategy (Wales, 2016), East Asian new ventures can enhance their performance through effectuation and swift adaptation to rapidly changing business environments. Furthermore, in order to obtain entrepreneurial finance, it is highly important for new ventures to leverage their human and social capital, which are strongly considered by investors in East Asia (Wang, 2016; Zacharakis et al., 2007). Finally, while networking generally has been found to be very important for East Asian new ventures, recent studies indicate that political networking, which appears to have been particularly prevalent in China, may result in problematic outcomes, such as weakening the effectiveness of entrepreneurial orientation (Su et al., 2015) or becoming an obstacle for acquiring customers (Luo et al., 2020). These findings suggest that new venture entrepreneurs should subsequently focus on developing business ties in their networking activities.

From a public policy perspective, entrepreneurial ecosystems research suggests that such ecosystems are strongly driven in East Asia by governmental investment and support (Hemmert et al., 2019), including the establishment of dedicated science parks for new ventures (Chen et al., 2020). While these policies appear to have been broadly effective for strengthening entrepreneurial ecosystems, research has also found that the services provided by science parks and incubators do not necessarily play a decisive role for new venture performance (Li \& Chen, 2009; Sung et al., 2003). These findings suggest that in order to remain effective in the future, entrepreneurship policy in East Asia should shift its emphasis from directly supporting new ventures towards more indirect measures, such as boundary-spanning and strengthening inter-regional and global connectivity, as can be found in globally advanced ecosystems (Brown \& Mawson, 2019).

\section{Limitations and conclusion}

One limitation of our review study is its focus on articles published in the English language, which we opted for to examine research which is globally visible. However, a large number of studies in entrepreneurship research in East Asia is published in local languages, such as Chinese, Japanese and Korean. A review of this non-English research may complement our analysis.

Furthermore, as the institutional setting and business environment for new venture entrepreneurship is rapidly changing in East Asian countries, the findings of early studies we have included in our review may become less and less relevant. In particular, institutional voids and institutional transitions may become less important in the future when China institutionally matures and as China's economy continues 
to grow. In view of the rapidly increasing number of articles on new venture entrepreneurship in East Asia, subsequent review studies may focus on articles which have been recently published.

Overall, our review has revealed that, whereas the research body on new venture entrepreneurship in East Asia is steeply expanding, the extant research is skewed towards Greater China and quantitative studies. Moreover, a majority of articles offers no or only a weak country-level contextualization. Future studies may advance our knowledge by focusing on new venture entrepreneurship in Japan and Korea, by applying qualitative methodologies, by considering the national or subnational context to a higher extent, and by developing indigenous theories of East Asian new venture entrepreneurship that bring new perspectives, models, practices and ideas to the general entrepreneurship literature.

Supplementary Information The online version contains supplementary material available at https://doi. org/10.1057/s41291-021-00163-1.

Acknowledgements This research has been supported by DIJ Tokyo, by a Korea University Business School Research Grant, by Global Research Network program through the Ministry of Education of the Republic of Korea and the National Research Foundation of Korea (NRF-2017S1A2A2041806), by JSPS KAKENHI Grant Number 18K12847, by Research Development Fund RDF15-02-50 awarded by Xi' an Jiaotong-Liverpool University (XJTLU), and by the Natural Science Foundation of Chongqing, China (Project number: cstc2020jcyj-msxmX0245). On behalf of all authors, the corresponding author states that there is no conflict of interest.

Funding Open Access funding enabled and organized by Projekt DEAL.

Open Access This article is licensed under a Creative Commons Attribution 4.0 International License, which permits use, sharing, adaptation, distribution and reproduction in any medium or format, as long as you give appropriate credit to the original author(s) and the source, provide a link to the Creative Commons licence, and indicate if changes were made. The images or other third party material in this article are included in the article's Creative Commons licence, unless indicated otherwise in a credit line to the material. If material is not included in the article's Creative Commons licence and your intended use is not permitted by statutory regulation or exceeds the permitted use, you will need to obtain permission directly from the copyright holder. To view a copy of this licence, visit http://creativecommons.org/licen ses/by/4.0/.

\section{References}

Ahlstrom, D., \& Bruton, G. D. (2006). Venture capital in emerging economies: Networks and institutional change. Entrepreneurship Theory and Practice, 30(2), 299-320.

Armanios, D. E., Eesley, C. E., Li, J., \& Eisenhardt, K. M. (2017). How entrepreneurs leverage institutional intermediaries in emerging economies to acquire public resources. Strategic Management Journal, 38(7), 1373-1390.

Bai, W., Johanson, M., \& Martín Martín, O. (2019). Dual business relationships, opportunity knowledge, and new product development: A study on returnee young ventures. Journal of International Marketing, 27(3), 26-42.

Bai, X., Tsang, E. W., \& Xia, W. (2020). Domestic versus foreign listing: Does a CEO's educational experience matter? Journal of Business Venturing, 35(1), 105906.

Batjargal, B., Hitt, M. A., Tsui, A. S., Arregle, J. L., Webb, J. W., \& Miller, T. L. (2013). Institutional polycentrism, entrepreneurs' social networks, and new venture growth. Academy of Management Journal, 56(4), 1024-1049. 
Batjargal, B., \& Liu, M. (2004). Entrepreneurs' access to private equity in China: The role of social capital. Organization Science, 15(2), 159-172.

Bauke, B., Semrau, T., \& Han, Z. (2016). Relational trust and new ventures' performance: The moderating impact of national-level institutional weakness. International Entrepreneurship and Management Journal, 12(4), 1007-1024.

Beeson, M. (2014). Regionalism and globalization in East Asia: Politics, security and economic development (2nd ed.). Palgrave Macmillan.

Brown, R., \& Mawson, S. (2019). Entrepreneurial ecosystems and public policy in action: A critique of the latest industrial policy blockbuster. Cambridge Journal of Regions, Economy and Society, 12(3), 347-368.

Bruton, G. D., Ahlstrom, D., \& Puky, T. (2009). Institutional differences and the development of entrepreneurial ventures: A comparison of the venture capital industries in Latin America and Asia. Journal of International Business Studies, 40(5), 762-778.

Bruton, G. D., Zahra, S. A., \& Cai, L. (2018). Examining entrepreneurship through indigenous lenses. Entrepreneurship and Practice, 42(3), 351-361.

Bryman, A. (2011). Mission accomplished? Research methods in the first five years of Leadership. Leadership, 7(1), 73-83.

CB Insights. (2021). Global unicorn club: Private companies valued at $\$ 1 B+($ as of July 8, 2021). CB Insights. Retrieved from https://www.cbinsights.com/research-unicorn-companies

Cai, L., Chen, B., Chen, J., \& Bruton, G. D. (2017a). Dysfunctional competition \& innovation strategy of new ventures as they mature. Journal of Business Research, 78, 111-118.

Cai, L., Guo, R., Fei, Y., \& Liu, Z. (2017b). Effectuation, exploratory learning and new venture performance: Evidence from China. Journal of Small Business Management, 55(3), 388-403.

Cai, L., Hughes, M., \& Yin, M. (2014). The relationship between resource acquisition methods and firm performance in Chinese new ventures: The intermediate effect of learning capability. Journal of Small Business Management, 52(3), 365-389.

Casson, M., \& Park, Y. (2014). Government intervention or entrepreneurial profit? Explaining innovation in the Korean online gaming industry. Industry and Innovation, 21(7-8), 616-632.

Chang, H.-C., Tsai, K.-H., \& Peng, C.-Y. (2014). The entrepreneurial process: An integrated model. International Entrepreneurship and Management Journal, 10(4), 727-745.

Chen, C. (2015). Effects of shared vision and integrations on entrepreneurial performance. Chinese Management Studies, 9(2), 150-175.

Chen, J., Cai, L., Bruton, G. D., \& Sheng, N. (2020). Entrepreneurial ecosystems: What we know and where we move as we build an understanding of China. Entrepreneurship \& Regional Development, 32(5-6), 370-388.

Choi, K., Park, J., Cho, D., \& Chu, H. Y. (2017). The impact of university support on the creation of student entrepreneurs: Evidence from South Korea. Entrepreneurship Research Journal, 8(1), 1-14.

Dai, Y., Roundy, P. T., Chok, J. I., Ding, F., \& Byun, G. (2016). 'Who knows what?' in new venture teams: Transactive memory systems as a micro-foundation of entrepreneurial orientation. Journal of Management Studies, 53(8), 1320-1347.

De Clercq, D., \& Zhou, L. (2014). Entrepreneurial strategic posture and performance in foreign markets: The critical role of international learning effort. Journal of International Marketing, 22(2), 47-67.

Delios, A. (2017). The death and rebirth (?) of international business research. Journal of Management Studies, 54(3), 391-397.

Ding, Z., Sun, S. L., \& Au, K. (2014). Angel investors' selection criteria: A comparative institutional perspective. Asia Pacific Journal of Management, 31(3), 705-731.

Du, Y., Kim, P. H., \& Aldrich, H. E. (2016). Hybrid strategies, dysfunctional competition, and new venture performance in transition economies. Management and Organization Review, 12(3), 469-501.

Eberhart, R. N., Eesley, C. E., \& Eisenhardt, K. M. (2017). Failure is an option: Institutional change, entrepreneurial risk, and new firm growth. Organization Science, 28(1), 93-112.

Eshima, Y., \& Anderson, B. S. (2017). Firm growth, adaptive capability, and entrepreneurial orientation. Strategic Management Journal, 38(3), 770-779.

Eto, H. (2005). Obstacles to emergence of high/new technology parks, ventures and clusters in Japan. Technological Forecasting and Social Change, 72(3), 359-373.

Eun, J. H., Lee, K., \& Wu, G. (2006). Explaining the "University-run enterprises" in China: A theoretical framework for university-industry relationship in developing countries and its application to China. Research Policy, 35(9), 1329-1346. 
Fang, S. C., Wang, M. C., \& Chen, P. C. (2017). The influence of knowledge networks on a firm's innovative performance. Journal of Management and Organization, 23(1), 22-45.

Fernhaber, S., Li, D., \& Wu, A. (2019). Internationalization of emerging-economy new ventures: The role of within-country differences. Business Horizons, 62(4), 497-507.

Ferreira, J. J., Fernandes, C. I., \& Kraus, S. (2019). Entrepreneurship research: Mapping intellectual structures and research trends. Review of Managerial Science, 13(1), 181-205.

Filatotchev, I., Liu, X., Lu, J., \& Wright, M. (2011). Knowledge spillovers through human mobility across national borders: Evidence from Zhongguancun Science Park in China. Research Policy, 40(3), $453-462$.

Fitz-Koch, S., Nordqvist, M., Carter, S., \& Hunter, E. (2018). Entrepreneurship in the agricultural sector: A literature review and future research opportunities. Entrepreneurship Theory and Practice, 42(1), 129-166.

Francis, D. H., \& Sandberg, W. R. (2000). Friendship within entrepreneurial teams and its association with team and venture performance. Entrepreneurship Theory and Practice, 25(2), 5-26.

Ge, J., Stanley, L. J., Eddleston, K., \& Kellermanns, F. W. (2017). Institutional deterioration and entrepreneurial investment: The role of political connections. Journal of Business Venturing, 32(4), $405-419$.

Gruenhagen, J. H. (2019). Returnee entrepreneurs and the institutional environment: Case study insights from China. International Journal of Emerging Markets, 14(1), 207-230.

Guo, R., Cai, L., \& Fei, Y. (2019). Knowledge integration methods, product innovation and high-tech new venture performance in China. Technology Analysis \& Strategic Management, 31(3), 306-318.

Guo, R., Lv, X., Wang, Y., Chaudhry, P. E., \& Chaudhry, S. S. (2020). Decision-making logics and hightech entrepreneurial opportunity identification: The mediating role of strategic knowledge integration. Systems Research and Behavioral Science, 37(4), 719-733.

Gupta, V., \& Hanges, P J. (2004). Regional and climate clustering of societal cultures. In: R. J. House, P. J. Hanges, M. Javidan, P. W. Dorfman, \& V. Gupta (Eds.), Culture, leadership, and organizations. The GLOBE study of 62 societies (pp. 178-218). Sage.

Hayter, C. S., Nelson, A. J., Zayed, S., \& O'Connor, A. C. (2018). Conceptualizing academic entrepreneurship ecosystems: A review, analysis and extension of the literature. The Journal of Technology Transfer, 43(4), 1039-1082.

Hemmert, M. (2020). Does Korean-style management have a future? Asian Business \& Management, 19(2), 147-170.

Hemmert, M., Cross, A. R., Cheng, Y., Kim, J. J., Kohlbacher, F., Kotosaka, M., Waldenberger, F., \& Zheng, L. J. (2019). The distinctiveness and diversity of entrepreneurial ecosystems in China, Japan, and South Korea: An exploratory analysis. Asian Business \& Management, 18(3), 211-247.

Hemmert, M., \& Kim, J.-J. (2021). Entrepreneurship in Korea: From chaebols to start-ups. Routledge.

Huang, H. C., Lai, M. C., \& Lo, K. W. (2012). Do founders' own resources matter? The influence of business networks on start-up innovation and performance. Technovation, 32(5), 316-327.

Huang, Q., Liu, X., \& Li, J. (2020). Contextualization of Chinese entrepreneurship research: An overview and some future research directions. Entrepreneurship \& Regional Development, 32(5-6), 353-369.

Hung, S. C., \& Chu, Y. Y. (2006). Stimulating new industries from emerging technologies: Challenges for the public sector. Technovation, 26(1), 104-110.

Ibata-Arens, K. (2009). Kyoto cluster culture: National and regional entrepreneurship strategy and policy in Japan and the United States. Asian Business \& Management, 8(4), 395-428.

Jiang, H., Cannella, A. A., \& Jiao, J. (2018). Does desperation breed deceiver? A behavioral model of new venture opportunism. Entrepreneurship Theory and Practice, 42(5), 769-796.

Jin, C. H. (2017). The effect of psychological capital on start-up intention among young start-up entrepreneurs. Chinese Management Studies, 11(4), 707-729.

Jing, S., Zhai, Q., \& Landström, H. (2015). Entrepreneurship research in three regions-the USA, Europe and China. International Entrepreneurship and Management Journal, 11(4), 861-890.

Jolivet, E., Lanciano-Morandat, C., Nohara, H., \& Pardo, D. (2009). Biopharmaceutical entrepreneurship in two Japanese and French bioclusters: Differences in founder profiles and experience. Asian Business \& Management, 8(4), 429-460.

Jones, M. V., Coviello, N., \& Tang, Y. K. (2011). International Entrepreneurship research (1989-2009): A domain ontology and thematic analysis. Journal of Business Venturing, 26(6), 632-659.

Jung, H., \& Kim, B. K. (2018). Determinant factors of university spin-off: The case of Korea. The Journal of Technology Transfer, 43(6), 1631-1646. 
Kawakami, T., MacLachlan, D. L., \& Stringfellow, A. (2012). New venture performance in China, Japan, and the United States: The impact of formalized market information processes. Journal of Product Innovation Management, 29(2), 275-287.

Khavul, S., Benson, G. S., \& Datta, D. K. (2010a). Is internationalization associated with investments in HRM? A study of entrepreneurial firms in emerging markets. Human Resource Management, 49(4), 693-713.

Khavul, S., Pérez-Nordtvedt, L., \& Wood, E. (2010b). Organizational entrainment and international new ventures from emerging markets. Journal of Business Venturing, 25(1), 104-119.

Knight, G. A., \& Liesch, P. W. (2016). Internationalization: From incremental to born global. Journal of World Business, 51(1), 93-102.

Kraus, S., Breier, M., \& Dasí-Rodríguez, S. (2020). The art of crafting a systematic literature review in entrepreneurship research. International Entrepreneurship and Management Journal, 16(3), 1023-1042.

Kroll, H., \& Liefner, I. (2008). Spin-off enterprises as a means of technology commercialisation in a transforming economy-Evidence from three universities in China. Technovation, 28(5), 298-313.

Kshetri, N. (2014). Developing successful entrepreneurial ecosystems. Baltic Journal of Management, 9(3), 330-356.

Kuratko, D. F., \& Morris, M. H. (2018). Examining the future trajectory of entrepreneurship. Journal of Small Business Management, 56(1), 11-23.

Lam, W. (2010). Funding gap, what funding gap? Financial bootstrapping. International Journal of Entrepreneurial Behavior \& Research, 16(4), 268-295.

Lau, C. M., \& Bruton, G. D. (2011). Strategic orientations and strategies of high technology ventures in two transition economies. Journal of World Business, 46(3), 371-380.

Lau, V. P., Dimitrova, M. N., Shaffer, M. A., Davidkov, T., \& Yordanova, D. I. (2012). Entrepreneurial readiness and firm growth: An integrated etic and emic approach. Journal of International Management, 18(2), 147-159.

Lau, V. P., Shaffer, M. A., \& Au, K. (2007). Entrepreneurial career success from a Chinese perspective: Conceptualization, operationalization, and validation. Journal of International Business Studies, 38(1), 126-146.

Lechevalier, S., Nishimura, J., \& Storz, C. (2014). Diversity in patterns of industry evolution: How an intrapreneurial regime contributed to the emergence of the service robot industry. Research Policy, 43(10), 1716-1729.

Lee, C. K., \& Hung, S. C. (2014). Institutional Entrepreneurship in the Informal Economy: China's ShanZhai Mobile Phones. Strategic Entrepreneurship Journal, 8(1), 16-36.

Li, H., \& Atuahene-Gima, K. (2002). The adoption of agency business activity, product innovation, and performance in Chinese technology ventures. Strategic Management Journal, 23(6), 469-490.

Li, H., \& Li, J. (2009). Top management team conflict and entrepreneurial strategy making in China. Asia Pacific Journal of Management, 26(2), 263-283.

Li, H., \& Zhang, Y. (2007). The role of managers' political networking and functional experience in new venture performance: Evidence from China's transition economy. Strategic Management Journal, 28(8), 791-804.

Li, H., Zhang, Y., Li, Y., Zhou, L. A., \& Zhang, W. (2012a). Returnees versus locals: Who perform better in China's technology entrepreneurship? Strategic Entrepreneurship Journal, 6(3), 257-272.

Li, J., Young, M. N., \& Tang, G. (2012b). The development of entrepreneurship in Chinese communities: An organizational symbiosis perspective. Asia Pacific Journal of Management, 29(2), 367-385.

Li, J., Qu, J., \& Huang, Q. (2018). Why are some graduate entrepreneurs more innovative than others? The effect of human capital, psychological factor and entrepreneurial rewards on entrepreneurial innovativeness. Entrepreneurship \& Regional Development, 30(5-6), 479-501.

Li, L., Chen, J., Gao, H., \& Xie, L. (2019). The certification effect of government R\&D subsidies on innovative entrepreneurial firms' access to bank finance: Evidence from China. Small Business Economics, 52(1), 241-259.

$\mathrm{Li}, \mathrm{X}$. (2017). Exploring the spatial heterogeneity of entrepreneurship in Chinese manufacturing industries. The Journal of Technology Transfer, 42(5), 1077-1099.

Li, Y. R., \& Chen, Y. (2009). Opportunity, embeddedness, endogenous resources, and performance of technology ventures in Taiwan's incubation centers. Technovation, 29(1), 35-44.

Li, Y., Wei, F., Chen, S., \& Yan, Y. (2020). Effects of CEO humility and relationship conflict on entrepreneurial performance. International Journal of Conflict Management, 31(3), 489-508. 
Lin, D., Lu, J., Li, P. P., \& Liu, X. (2015). Balancing formality and informality in business exchanges as a duality: A comparative case study of returnee and local entrepreneurs in China. Management and Organization Review, 11(2), 315-342.

Lin, H., Murphree, M., \& Li, S. (2017). Emergence of organizational routines in entrepreneurial ventures. Chinese Management Studies, 11(3), 498-519.

Lin, S., \& Wang, S. (2019). How does the age of serial entrepreneurs influence their re-venture speed after a business failure? Small Business Economics, 52(3), 651-666.

Lin, Y. H., Chen, C. J., \& Lin, B. W. (2014). The roles of political and business ties in new ventures: Evidence from China. Asian Business \& Management, 13(5), 411-440.

Liñán, F., \& Chen, Y. W. (2009). Development and cross-cultural application of a specific instrument to measure entrepreneurial intentions. Entrepreneurship Theory and Practice, 33(3), 593-617.

Liu, J., Chen, J., \& Tao, Y. (2015). Innovation performance in new product development teams in China's technology ventures: The role of behavioral integration dimensions and collective efficacy. Journal of Product Innovation Management, 32(1), 29-44.

Liu, R., Weng, Q., Mao, G., \& Huang, T. (2013). Industrial cluster, government agency and entrepreneurial development. Chinese Management Studies, 7(2), 253-280.

Liu, Z., Wu, H., \& Wu, J. (2019a). Location-based tax incentives and entrepreneurial activities: Evidence from Western Regional Development Strategy in China. Small Business Economics, 52(3), 729-742.

Liu, Z., Xu, Z., Zhou, Z., \& Li, Y. (2019b). Buddhist entrepreneurs and new venture performance: The mediating role of entrepreneurial risk-taking. Small Business Economics, 52(3), 713-727.

Lopez, T., \& Alvarez, C. (2018). Entrepreneurship research in Latin America: A literature review. Academia Revista Latinoamericana De Administración, 31(4), 736-756.

Lu, J., \& Tao, Z. (2010). Determinants of entrepreneurial activities in China. Journal of Business Venturing, 25(3), 261-273.

Lu, Y., Zhou, L., Bruton, G., \& Li, W. (2010). Capabilities as a mediator linking resources and the international performance of entrepreneurial firms in an emerging economy. Journal of International Business Studies, 41(3), 419-436.

Luo, X. R., Yang, L., \& He, X. (2020). Can one stone kill two birds? Political relationship building and partner acquisition in new ventures. Entrepreneurship Theory and Practice, 44(4), $817-841$.

Ma, C., Liu, H., Gu, J., \& Dou, J. (2018). How entrepreneurs' Zhong-yong thinking improves new venture performance. Chinese Management Studies, 12(2), 323-345.

Mai, Y., Zhang, W., \& Wang, L. (2019). The effects of entrepreneurs' moral awareness and ethical behavior on product innovation of new ventures. Chinese Management Studies, 13(2), 421-446.

Marquis, C., \& Qiao, K. (2020). Waking from Mao's dream: Communist ideological imprinting and the internationalization of entrepreneurial ventures in China. Administrative Science Quarterly, 65(3), 795-830.

Meyer, K. E. (2007). Asian contexts and the search for general theory in management research: A rejoinder. Asia Pacific Journal of Management, 24(4), 527-534.

Meyer, M., Libaers, D., Thijs, B., Grant, K., Glänzel, W., \& Debackere, K. (2014). Origin and emergence of entrepreneurship as a research field. Scientometrics, 98(1), 473-485.

Motohashi, K. (2013). The role of the science park in innovation performance of start-up firms: An empirical analysis of Tsinghua Science Park in Beijing. Asia Pacific Business Review, 19(4), 578-599.

Mu, J., \& Di Benedetto, C. A. (2011). Strategic orientations and new product commercialization: Mediator, moderator, and interplay. $R \& D$ Management, 41(4), 337-359.

Munir, H., Cai, J., \& Ramzan, S. (2019). Personality traits and theory of planned behavior comparison of entrepreneurial intentions between an emerging economy and a developing country. International Journal of Entrepreneurial Behavior \& Research, 25(3), 554-580.

Murmann, J. P., Ozdemir, S. Z., \& Sardana, D. (2015). The role of home country demand in the internationalization of new ventures. Research Policy, 44(6), 1207-1225.

Ng, B. K., Chen, S. H., Wong, C. Y., \& Chandran, V. (2019). University incubation system for research commercialisation: The case of Taiwan and Malaysia. Science, Technology and Society, 24(3), 465-485.

Ng, J. C. Y., Huang, M. M. D., \& Liu, Y. (2016). The 'feminine' entrepreneurial personality trait: The competitive advantage of female college-student entrepreneurs in Chinese wei-shang businesses? Asian Business \& Management, 15(5), 343-369. 
Ni, H., Luan, T., Cao, Y., \& Finlay, D. C. (2014). Can venture capital trigger innovation? New evidence from China. International Journal of Technology Management, 65(1-4), 189-214.

Pan, F., \& Yang, B. (2019). Financial development and the geographies of startup cities: Evidence from China. Small Business Economics, 52(3), 743-758.

Paul, J., \& Criado, A. P. (2020). The art of writing literature review: What do we know and what do we need to know? International Business Review, 29, 101717.

Pereira, A. A. (2004). State entrepreneurship and regional development: Singapore's industrial parks in Batam and Suzhou. Entrepreneurship \& Regional Development, 16(2), 129-144.

Qin, F., Wright, M., \& Gao, J. (2017). Are 'sea turtles' slower? Returnee entrepreneurs, venture resources and speed of entrepreneurial entry. Journal of Business Venturing, 32(6), 694-706.

Rauch, A., Frese, M., Wang, Z. M., Unger, J., Lozada, M., Kupcha, V., \& Spirina, T. (2013). National culture and cultural orientations of owners affecting the innovation-growth relationship in five countries. Entrepreneurship \& Regional Development, 25(9-10), 732-755.

Shahab, Y., Ye, C., Arbizu, A. D., \& Haider, M. J. (2019). Entrepreneurial self-efficacy and intention: Do entrepreneurial creativity and education matter? International Journal of Entrepreneurial Behavior \& Research, 25(2), 259-280.

Shan, B., \& Lu, X. (2020). Founder's social ties, learning and entrepreneurial knowledge acquisition in China. Asia Pacific Business Review, 26(2), 209-229.

Shepherd, D. A., Wennberg, K., Suddaby, R., \& Wiklund, J. (2019). What are we explaining? A review and agenda on initiating, engaging, performing, and contextualizing entrepreneurship. Journal of Management, 45(1), 159-196.

Shepherd, D. A., Souitaris, V., \& Gruber, M. (2021). Creating new ventures: A review and research agenda. Journal of Management, 47(1), 11-42.

Siu, W. S., \& Lo, E. S. C. (2013). Cultural contingency in the cognitive model of entrepreneurial intention. Entrepreneurship Theory and Practice, 37(2), 147-173.

Startup Genome. (2020). The global startup ecosystem report: The new normal for the global startup economy and the impact of COVID-19. San-Francisco: Startup Genome LLC. Retrieved from https://www.startupgenome.com

$\mathrm{Su}, \mathrm{N}$. (2013). Internationalization strategies of Chinese IT service suppliers. MIS Quarterly, 37(1), 175-200.

Su, Z., Xie, E., \& Wang, D. (2015). Entrepreneurial orientation, managerial networking, and new venture performance in China. Journal of Small Business Management, 53(1), 228-248.

Sung, T. K., Gibson, D. V., \& Kang, B. S. (2003). Characteristics of technology transfer in business ventures: The case of Daejeon, Korea. Technological Forecasting and Social Change, 70(5), 449-466.

Suzuki, K. I., Kim, S. H., \& Bae, Z. T. (2002). Entrepreneurship in Japan and Silicon Valley: A comparative study. Technovation, 22(10), 595-606.

Tang, M. F., Lee, J., Liu, K., \& Lu, Y. (2014). Assessing government-supported technology-based business incubators: Evidence from China. International Journal of Technology Management, 65(1-4), 24-48.

Tang, M., Walsh, G. S., Li, C., \& Baskaran, A. (2021). Exploring technology business incubators and their business incubation models: Case studies from China. The Journal of Technology Transfer, 46(1), 90-116.

Tourish, D. (2020). The triumph of nonsense in management studies. Academy of Management Learning \& Education, 19(1), 99-109.

Unger, J. M., Rauch, A., Frese, M., \& Rosenbusch, N. (2011). Human capital and entrepreneurial success: A meta-analytical review. Journal of Business Venturing, 26(3), 341-358.

Wales, W. J. (2016). Entrepreneurial orientation: A review and synthesis of promising research directions. International Small Business Journal, 34(1), 3-15.

Wang, T., Jiao, H., Xu, Z., \& Yang, X. (2018). Entrepreneurial finance meets government investment at initial public offering: The role of minority state ownership. Corporate Governance: An International Review, 26(2), 97-117.

Wang, C. L., Tee, D. D., \& Ahmed, P. K. (2012). Entrepreneurial leadership and context in Chinese firms: A tale of two Chinese private enterprises. Asia Pacific Business Review, 18(4), 505-530.

Wang, Y. (2016). Bringing the stages back in: Social network ties and start-up firms' access to venture capital in China. Strategic Entrepreneurship Journal, 10(3), 300-317.

Wang, Y., Li, J., \& Furman, J. L. (2017). Firm performance and state innovation funding: Evidence from China's Innofund program. Research Policy, 46(6), 1142-1161. 
Watkins-Mathys, L., \& Foster, M. J. (2006). Entrepreneurship: The missing ingredient in China's STIPs? Entrepreneurship and Regional Development, 18(3), 249-274.

Welter, F. (2011). Contextualizing entrepreneurship-Conceptual challenges and ways forward. Entrepreneurship Theory and Practice, 35(1), 165-184.

Welter, F., \& Gartner, W. B. (Eds.). (2016). A research agenda for entrepreneurship and context. Edward Elgar.

White, S., Gao, J., \& Zhang, W. (2005). Financing new ventures in China: System antecedents and institutionalization. Research Policy, 34(6), 894-913.

Williams, C., Du, J., \& Zhang, H. (2020). International orientation of Chinese internet SMEs: Direct and indirect effects of foreign and indigenous social networking site use. Journal of World Business, 55(3), 101051.

Wong, C. Y., Hsieh, Y. C., Wu, C. Y., \& Hu, M. C. (2019). Academic entrepreneurship for social innovation in Taiwan: The cases of the OurCityLove platform and the Forest App. Science, Technology and Society, 24(3), 446-464.

Wu, L. Y., Wang, C. J., Tseng, C. Y., \& Wu, M. C. (2009). Founding team and start-up competitive advantage. Management Decision, 47(2), 345-358.

Xiao, L., \& North, D. (2017). The graduation performance of technology business incubators in China's three tier cities: The role of incubator funding, technical support, and entrepreneurial mentoring. The Journal of Technology Transfer, 42(3), 615-634.

Xie, K., Song, Y., Zhang, W., Hao, J., Liu, Z., \& Chen, Y. (2018). Technological entrepreneurship in science parks: A case study of Wuhan Donghu High-Tech Zone. Technological Forecasting and Social Change, 135, 156-168.

Xie, X., \& Lv, J. (2016). Social networks of female tech-entrepreneurs and new venture performance: The moderating effects of entrepreneurial alertness and gender discrimination. International Entrepreneurship and Management Journal, 12(4), 963-983.

Xie, X., \& Lv, J. (2018). Female technology entrepreneurs: Resource shortages and reputation challenges-A view of institutional support. International Entrepreneurship and Management Journal, 14(2), 379-403.

Xie, X. Y., Feng, W., \& Hu, Q. (2020). Does new venture team power hierarchy enhance or impair new venture performance? A contingency perspective. Journal of Business Venturing, 35(6), 106059.

Xiong, L. (2020). Improvise to win: the relationship between entrepreneurial improvisation and startup competitive advantage. Asian Business \& Management, published online. Retrieved from https://doi.org/10.1057/s41291-020-00117-z.

Xu, Z. J., Wang, L., \& Long, J. (2017). The impact of director's heterogeneity on IPO underpricing. Chinese Management Studies, 11(2), 230-247.

Yamakawa, Y., Khavul, S., Peng, M. W., \& Deeds, D. L. (2013). Venturing from emerging economies. Strategic Entrepreneurship Journal, 7(3), 181-196.

Yang, C. H., Motohashi, K., \& Chen, J. R. (2009). Are new technology-based firms located on science parks really more innovative? Evidence from Taiwan. Research Policy, 38(1), 77-85.

Yang, G., \& Wang, R. (2013). The institutionalization of an electronic marketplace in China, 19982010. Journal of Product Innovation Management, 30(1), 96-109.

Yi, G. (2021). From green entrepreneurial intentions to green entrepreneurial behaviors: The role of university entrepreneurial support and external institutional support. International Entrepreneurship and Management Journal, 17(2), 963-979.

Yu, C., Ye, B., \& Ma, S. (2020). Creating for others: Linking prosocial motivation and social entrepreneurship intentions. Management Decision, published online. Retrieved from https://doi.org/ 10.1108/MD-06-2019-0815/full/html.

Yu, W. (2020). Creative industries agglomeration and entrepreneurship in China: Necessity or opportunity? Industry and Innovation, 27(4), 420-443.

Zacharakis, A. L., McMullen, J. S., \& Shepherd, D. A. (2007). Venture capitalists' decision policies across three countries: An institutional theory perspective. Journal of International Business Studies, 38(5), 691-708.

Zaheer, H., Breyer, Y., \& Dumay, J. (2019). Digital entrepreneurship: An interdisciplinary structured literature review and research agenda. Technological Forecasting and Social Change, 148, $1-20$.

Zahra, S. A. (2007). Contextualizing theory building in entrepreneurship research. Journal of Business Venturing, 22(3), 443-452. 
Zahra, S. A., Wright, M., \& Abdelgawad, S. G. (2014). Contextualization and the advancement of entrepreneurship research. International Small Business Journal, 32(5), 479-500.

Zhang, C., Tan, J., \& Tan, D. (2016). Fit by adaptation or fit by founding? A comparative study of existing and new entrepreneurial cohorts in China. Strategic Management Journal, 37(5), 911-931.

Zhang, M. Y., \& Dodgson, M. (2007). "A roasted duck can still fly away": A case study of technology, nationality, culture and the rapid and early internationalization of the firm. Journal of World Business, 42(3), 336-349.

Zhang, W., \& White, S. (2016). Overcoming the liability of newness: Entrepreneurial action and the emergence of China's private solar photovoltaic firms. Research Policy, 45(3), 604-617.

Zhang, Y., \& Li, H. (2010). Innovation search of new ventures in a technology cluster: The role of ties with service intermediaries. Strategic Management Journal, 31(1), 88-109.

Zhao, Y., Xie, X., \& Yang, L. (2020). Female entrepreneurs and equity crowdfunding: The consequential roles of lead investors and venture stages. International Entrepreneurship and Management Journal, published online. Retrieved from https://doi.org/10.1007/s11365-020-00659-w

Zhao, Y. L., Libaers, D., \& Song, M. (2015). First product success: A mediated moderating model of resources, founding team startup experience, and product-positioning strategy. Journal of Product Innovation Management, 32(3), 441-458.

Zheng, Y. (2012). Unlocking founding team prior shared experience: A transactive memory system perspective. Journal of Business Venturing, 27(5), 577-591.

Zhou, J., Ge, L. G., Li, J., \& Chandrashekar, S. P. (2020). Entrepreneurs' socioeconomic status and government expropriation in an emerging economy. Strategic Entrepreneurship Journal, 14(3), 396-418.

Zhou, L., \& Wu, A. (2014). Earliness of internationalization and performance outcomes: Exploring the moderating effects of venture age and international commitment. Journal of World Business, 49(1), $132-142$.

Zhou, W. (2016). When does shared leadership matter in entrepreneurial teams: The role of personality composition. International Entrepreneurship and Management Journal, 12(1), 153-169.

Zhou, W. (2017). Institutional environment, public-private hybrid forms, and entrepreneurial reinvestment in a transition economy. Journal of Business Venturing, 32(2), 197-214.

Zou, H., \& Ghauri, P. N. (2010). Internationalizing by learning: The case of Chinese high-tech new ventures. International Marketing Review, 27(2), 223-244.

Publisher's Note Springer Nature remains neutral with regard to jurisdictional claims in published maps and institutional affiliations.

\title{
Authors and Affiliations
}

\section{Martin Hemmert ${ }^{1}$ iD $\cdot$ Adam R. Cross $^{2}$ - Ying Cheng ${ }^{3} \cdot$ Jae-Jin Kim $^{4}$. Masahiro Kotosaka ${ }^{5} \cdot$ Franz Waldenberger $^{6} \cdot$ Leven J. Zheng $^{7}$}

\author{
Adam R. Cross \\ adam.cross@xjtlu.edu.cn \\ Ying Cheng \\ chengying@cqu.edu.cn \\ Jae-Jin Kim \\ jkim@hoseo.edu \\ Masahiro Kotosaka \\ kotosaka@sfc.keio.ac.jp \\ Franz Waldenberger \\ waldenberger@dijtokyo.org \\ Leven J. Zheng \\ Jianwen.Zheng02@xjtlu.edu.cn
}


1 School of Business, Korea University, 145 Anam-ro, Seongbuk-gu, Seoul 02841, South Korea

2 Department of International Studies, Xi' an Jiaotong-Liverpool University, 8 Chongwen Road, Suzhou 215123, People's Republic of China

3 School of Economics and Business Administration, Chongqing University, 174 Shapingba Street, Chongqing 400044, People's Republic of China

4 School of Business Administration, Hoseo University, Hoseodae-gil 12, Dongnam-gu, Cheonan-si, South Korea

5 Faculty of Policy Management, Keio University, 5322 Endo, Fujisawa, Kanagawa 252-0882, Japan

6 German Institute for Japanese Studies, Kioicho 7-1, Chiyoda-ku, Tokyo 102-0094, Japan

7 International Business School Suzhou, Xi'an Jiaotong-Liverpool University, 8 Chongwen Road, Suzhou 215123, People's Republic of China 